\title{
PROSPECTS FOR THE USE OF THERMOTOLERANT MICROORGANISMS FOR REMEDIATION OF OIL-CONTAMINATED SOILS
}

\author{
Aitkeldiyeva S.A., Faizulina E.R., Tatarkina L.G., Alimbetova A.V., \\ Auezova O.N., Spankulova G.A. \\ Research and Production Center for Microbiology and Virology \\ 105, Bogenbai batyr str., Almaty, 050010, Kazakhstan \\ sa.kz@list.ru, ecomicrolab@gmail.com
}

\begin{abstract}
Most of the world's oil fields are concentrated in geographic areas with high temperature conditions. One of the main problems of remediation of territories in hot climates is the fact that high temperatures reduce the viscosity of oil and, thus, accelerate its diffusion into the soil. This greatly complicates the processes of soil cover restoration using conventional methods. An alternative can be bioremediation using the oil-oxidizing microorganisms that are resistant to high temperatures and low humidity. The presented review is devoted to the analysis of studies of thermotolerant microorganisms by scientists from different countries with the aim of using them in the remediation of contaminated soils from oil and oil products. The data on the influence of the main environmental factors, such as temperature, oxygen, $\mathrm{pH}$, salinity, aeration, the presence of nutrients, etc., on the viability and vital activity of thermotolerant hydrocarbon-oxidizing microorganisms are presented. Examples of biochemical and molecular genetic characteristics of thermotolerant microorganisms are given. Their taxonomic diversity is shown, and examples of the degradation of individual oil components by active strains are given.
\end{abstract}

Key words: thermotolerant microorganism, bioremediation, oil, oil destructor, temperature

Among the energy resources of our planet, oil and petroleum hydrocarbons are the main environmental pollutants. Starting from the exploration and production of oil, and ending with the use of petroleum products, all stages to one degree or another lead to severe environmental pollution and negative impact on human health. By entering the soil, oil products worsen the overall environmental situation, significantly changing the agrophysical and agrochemical properties of soils. The decomposition of oil and oil products in the soil under natural conditions is a biochemical process. The intensity of oil degradation is directly dependent on the biological (enzymatic) activity of the soil, the total amount of soil microflora and its physiological activity [1].

According to the United States Environmental Protection Agency (EPA USA), the amount of contaminated soil exceeds 1 billion cubic meters. Only in the EU there are more than one and a half million contaminated sites, the cleaning of which requires more than 85 billion Euros [2].

More than half of the world's oil is produced in the Persian Gulf, the coast of which belongs to the territories of Qatar, Bahrain, Oman, the United Arab Emirates, Saudi Arabia, Kuwait, Iraq and Iran. Kazakhstan takes 8th place in world proven oil reserves. Only Saudi Arabia, Iran, Iraq, Kuwait, the United Arab Emirates, Venezuela and Russia are ahead of him. The total forecast hydrocarbon resources are estimated at 
12-17 billion tons [3]. According to forecasts, global oil demand by 2030 will increase by $37 \%$ compared to 2006 and will reach 118 million barrels per day. With such volumes of consumption, environmental problems caused by the release of oil into the environment will reach a critical level. The main risk of oil and oil products pollution is in the regions where the fields are located and oil is being extracted. About $60 \%$ of the world's oil reserves are located in countries with hot climates, where the specifics of natural, in particular, temperature conditions force a more careful approach to the choice of remediation method for contaminated lands [4].

The growing need for restoration of contaminated sites has led to the development of new technologies that focus on biological detoxification and the destruction of organic pollutants. Bioremediation is one of these technologies. Using this technology, various pollutants are destroyed or neutralized, while using the biological activity of certain groups of microorganisms. The use of bioremediation provides significant advantages in the fight against environmental pollution, however, due to the variability of pollutants and their possible biotransformation into uncontrolled metabolites, the risk of developing adverse effects on human health is possible [5]. Bioremediation technologies can be divided into two main categories: ex situ and in situ. Ex situ are methods that require the physical removal of contaminated material and its transportation to another area for further processing, for example, using bioreactors, farming and composting. In situ technologies include manipulations in which contaminated material is processed locally, for example, by bioventilation and biostimulation. In general, bioremediation is considered a very promising technology with great potential when working with certain types of contaminated sites.

The bioremediation method is based on the use of active microbial strains exhibiting the ability to degrade oil hydrocarbons. Hydrocarbon-oxidizing microorganisms (HOMs) decompose petroleum hydrocarbons at a very high speed, since they have high enzymatic activity, they multiply rapidly. They are able to use oil hydrocarbons as the sole source of carbon and bring the process of transformation of organic matter to full mineralization. As a result of biochemical processes, natural pollutants are converted into carbon dioxide, water, and other environmentally neutral compounds. That is why bioremediation of soils contaminated with oil and oil products, by active strains of hydrocarbon-oxidizing microorganisms is proposed as the most promising method of combating this pollution [6].

Since the problem of pollution of natural ecosystems with oil and oil products is extremely acute, research on the bioremediation of soil and water from these pollutants is being conducted in many countries. The degradation of petroleum products involves the use of both individual strains of microorganisms and their associations. In nature, a complex of consortium species formed in a given biotope is usually involved in oil biodegradation. For active oil degradation, a combination of bacterial strains with wide enzymatic capabilities is necessary - in this case, the process of removing the pollutant from the ecosystem is most effective [7]. It was noted that the use of consortia of hydrocarbon-oxidizing microorganisms leads to the most complete destruction of these compounds [8].

In addition, the introduction of hydrocarbon-oxidizing microorganisms into the existing microbocenosis may prove to be ineffective due to possible antagonism with indigenous microflora. Therefore, it is preferable in the elimination of local pollution by oil products to isolate microorganisms - oil product destructors adapted to specific conditions.

The following main factors influence the activity of microorganisms: temperature, oxygen, $\mathrm{pH}$, salinity, aeration, the presence of nutrients, etc. (Figure 1) [9]. 


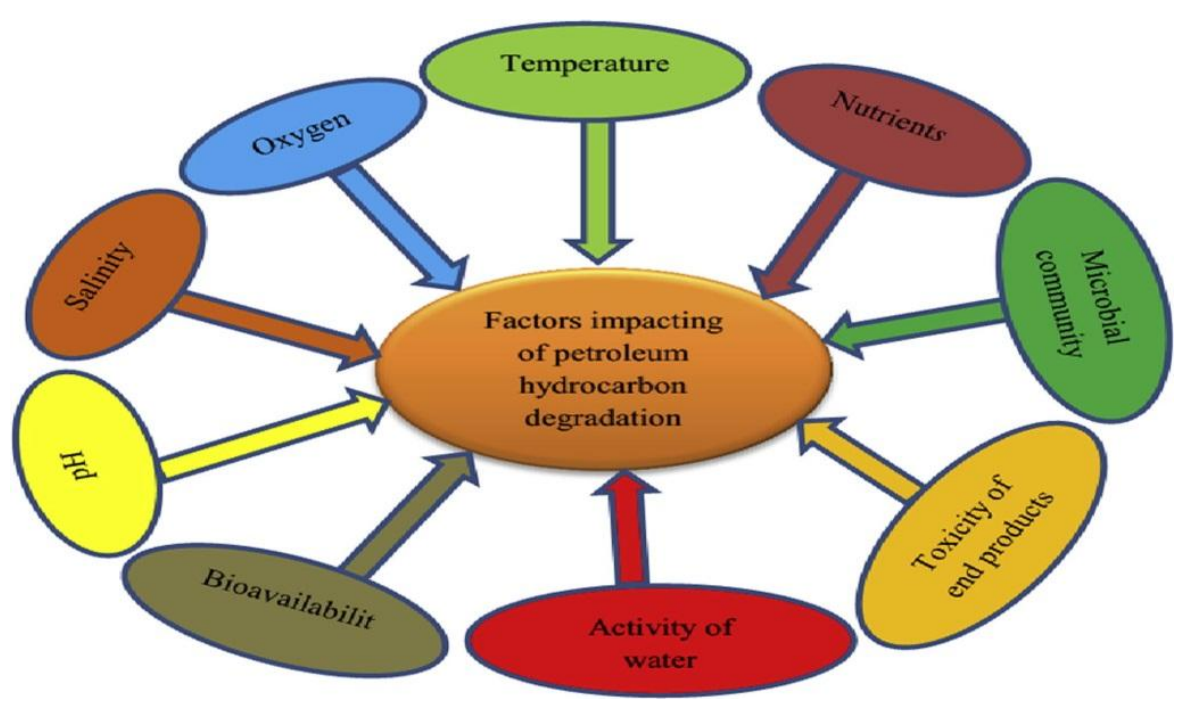

Fig. 1 Factors affecting the biodegradation of petroleum hydrocarbons

Under natural conditions, microorganisms are exposed to abiotic factors, significantly different in nature and mechanism of action. Nevertheless, the nature of the dependence of microorganism vital activity indicator on the level of various external factors is similar. For any abiotic factor, there is a range of changes within which the vital signs of the microorganism practically do not change, remaining at a level called optimal. Lower levels of the factor do not ensure the full functioning of the microorganism, limiting the intensity of its vital processes, and the corresponding interval is called the limiting zone. Excessive factor levels inhibit the activity of microorganisms, and this interval is called the zone of inhibition. There are extremely high and extremely low factor levels at which the vital activity of a microorganism becomes impossible. The extreme limits of the factor changes that the body is able to tolerate are commonly called tolerance limits. Different microorganisms have significantly different limits of tolerance to the same environmental factor [10].

Temperature is one of the key factors affecting the physical properties and chemical composition of petroleum hydrocarbons, and, consequently, their biodegradation. At low temperatures, a decrease in the rate of degradation is usually observed, which is believed to be the result of a decrease in the rate of enzymatic activity [11].

Aislabie J. et al. [12] and Okoh A.I. [13] by their studies proved that elevated temperature increases the solubility of hydrocarbon pollutants, reduces viscosity and transfers long chain n-alkanes from the solid phase to the aqueous phase. Thamer M. et al. showed that high salinity and temperature inhibit the growth of microorganisms and the release of their metabolites [14].

The rate of hydrocarbon biodegradation depends on the level of oxygen in the soil, the degree of oxygen consumption by microorganisms, and the type of soil. Studies have shown that anaerobic degradation of petroleum hydrocarbons by microorganisms can occur at an insignificant rate [15]. Mc Nally D.L. et al. [16] reported that aerobic biodegradation of petroleum hydrocarbons was higher compared to anaerobic biodegradation. It was proved that the rate of biodegradation of petroleum hydrocarbons under anaerobic conditions was not as high as under aerobic conditions [17]. Anaerobic degradation processes are less studied than aerobic ones $[18,19]$. It should be noted that BTEX (benzene, toluene, ethylbenzene, xylene) compounds undergo degradation at approximately the same rate, both during aerobic and anaerobic metabolism [20]. During anaerobic metabolism, these aromatic compounds are first oxidized to phenols or organic acids and then converted to long chain volatile fatty acids, which are 
ultimately metabolized to $\mathrm{CH}_{4}$ and $\mathrm{CO}_{2}$ [19-21]. During anaerobic degradation of oil hydrocarbons, electron acceptors are nitrate ions, ferrous, manganese or sulfate ions [21, 22].

Abed R.M.M. et al. [23] found that the coastline of the Persian Gulf is inhabited mainly by anaerobic sulfate-reducing microorganisms of the Gamma- and Deltaproteobacteria groups. It was found that oil pollution stimulates the microorganisms involved in the sulfur cycle, and sulfate reducers are often destructors of oil hydrocarbons [24]. The detection of such bacteria indicates anaerobic degradation of oil, which was confirmed by the selected samples of the microbial mat. At the same time, well-known aerobic destructors of such genera as Pseudomonas and Alcanivorax, Abed R.M.M. et al. not found [23].

In addition to temperature and aeration, salinity also has a significant effect on the process of bioremediation and biodegradation, as well as on the growth and diversity of microbes [25]. It was proved that salinity has an adverse effect on the activity of some key enzymes involved in the biodegradation of hydrocarbons [26]. Halophilic bacteria degrading hydrocarbons have been described by many researchers. Previously Ben Ali Gam Z. et al. [27] from an oil well in Tunisia isolated a strain of Lit2 belonging to the genus Modicisalibacter and capable of growth in the temperature range of $15-45{ }^{\circ} \mathrm{C}$ with an optimum of $37{ }^{\circ} \mathrm{C}$. The strain withstood up to $25 \%$ of the salt in the medium, but the optimal concentration for it was $10 \% \mathrm{NaCl}$ in the medium. Wang Y.N. et al. [28] isolated the strain DQS3-9A1 from a field in China and described a new genus Amicolicicoccus and a new species A. subflavus on its basis. The strain grew in the temperature range $15-42^{\circ} \mathrm{C}$ with an optimum of $37^{\circ} \mathrm{C}, \mathrm{pH}$ 6-11 (optimum 8) and in the presence of salt in the medium 1-12\% (optimum $8 \%$ ).

The $\mathrm{pH}$ can vary greatly in both soil and water and must be taken into account to improve biological treatment methods. The $\mathrm{pH}$ of the medium affects processes such as cell membrane transport, the balance of catalytic reactions, and enzyme activity [29]. Most heterotrophic bacteria prefer to grow at a $\mathrm{pH}$ of neutral to alkaline. Unlike the $\mathrm{pH}$ of most aquatic ecosystems, soil acidity can vary greatly from 2.5 to $11 \mathrm{pH}$ in alkaline deserts [30]. In general, heterotrophic fungi and bacteria prefer an almost neutral $\mathrm{pH}$, although fungi are tolerant to acidic conditions. Thavasi R. et al. [31] found that the maximum biodegradation of crude oil by Pseudomonas aeruginosa in water was at $\mathrm{pH}$ 8.0. R. Pawar [32] noted that a soil $\mathrm{pH}$ of 7.5 was most optimal for the degradation of virtually all petroleum hydrocarbons.

Bioavailability is the presence of a chemical in the soil that can be absorbed or converted by living organisms. The physicochemical properties and bioavailability of hydrocarbon pollutants play a very important role for successful bioremediation [33, 34]. Oil pollution has low bioavailability and is classified as hydrophobic organic pollutants. These chemicals have little solubility in water, which makes them resistant to photolytic destruction and chemical biological effects [35]. When all of the above conditions are favorable for microorganisms, the biodegradation of petroleum hydrocarbons reaches a maximum level.

Soil pollution with oil and oil products is an urgent problem for Kazakhstan. It is known that in the oil-producing regions of Kazakhstan, the climate is sharply continental, characterized by sharp seasonal and daily temperature differences, high rates of water evaporation and, as a result, salinity and low soil moisture. In hot climates, volatile hydrocarbon fractions evaporate quickly, and the remaining longchain aliphatic and aromatic components are more difficult to degrade and can remain in the environment for a long time. Therefore, research related to the search and study of thermotolerant hydrocarbon-oxidizing oil-degrading microorganisms is currently very relevant. 
For thermotolerant oil-oxidizing microorganisms, the temperature regime is one of the main factors for the oxidation of oil hydrocarbons. Depending on the temperature, bacterial activity and biodegradation rates may vary seasonally [36, 37].

One of the main problems of remediation of territories in hot climates is the fact that high temperatures reduce the viscosity of oil and, thus, accelerate its diffusion deep into the soil. In addition, the evaporation of light oil fractions at elevated temperatures leads to air pollution with toxic products, while the remaining non-volatile components with a high molecular weight form films that are poorly biodegradable. At the same time, the increased average daily temperatures are the reason for the rapid evaporation of water from the soil and from the surface of water bodies, which leads to their salinization. Therefore, microorganisms' resistant to a lack of water in the soil and an increased salt content in the treated area are promising agents for the remediation of oilcontaminated sites in high-temperature regions [38].

Temperature has a huge impact on many aspects of the life of organisms - the geography of their distribution, reproduction and other biological properties. The temperature range in which life can exist ranges from about $-200^{\circ} \mathrm{C}$ to $+100^{\circ} \mathrm{C}$, sometimes the existence of bacteria in hot springs is detected at a temperature of $+250^{\circ} \mathrm{C}$. In fact, most organisms can exist at a narrower temperature range. All chemical processes in the organism depend on temperature. Changes in thermal conditions, often observed in nature, deeply affect the growth, development and other manifestations of the vital activity of animals and plants.

In relation to temperature, microorganisms are divided into the following groups: psychrophilic (minimum - about $0^{\circ} \mathrm{C}$, maximum - below $20^{\circ} \mathrm{C}$ ); psychroactive / psychrotrophic (minimum - about $0^{\circ} \mathrm{C}$, optimum and maximum - above $20^{\circ} \mathrm{C}$ ); mesophilic (minimum - above $0^{\circ} \mathrm{C}$, maximum - up to $45^{\circ} \mathrm{C}$ ); thermophilic (maximum above $45^{\circ} \mathrm{C}$ ).

Thermophilic microorganisms are divided into 5 groups depending on the temperature range:

1. Thermotolerant (minimum $-+10^{\circ} \mathrm{C}$; optimum $-+35-40^{\circ} \mathrm{C}$, as in mesophiles; maximum - $\left.+55-60^{\circ} \mathrm{C}\right)$ : gram-negative bacteria Methylococcus capsulatus; red algae Cyanidium caldarium;

2. Optional thermophiles (minimum - below $+20^{\circ} \mathrm{C}$; maximum $-+55-65^{\circ} \mathrm{C}$ ): homoenzymatic lactic acid bacteria of the genus Lactobacillus, cyanobacteria Thermosynechococcus elongatus;

3. Obligatory thermophiles (minimum $-+40^{\circ} \mathrm{C}$; optimum - adjacent to the upper boundary $\left(+65-70^{\circ} \mathrm{C}\right)$; maximum - above $\left.+70^{\circ} \mathrm{C}\right)$ : Bacilluss tearothermophilus;

4. Extreme thermophiles (minimum - above $+40^{\circ} \mathrm{C}$; optimum - $+70-75^{\circ} \mathrm{C}$; maximum - above $\left.+90^{\circ} \mathrm{C}\right)$ : bacteria Thermus, Thermomicrobium, archaea Thermoplasma;

5. Hyperthermophiles (minimum - about $+70^{\circ} \mathrm{C}$; optimum - above $+80^{\circ} \mathrm{C}$; maximum - above $\left.+100^{\circ} \mathrm{C}\right)$ : archaea Geogemmabarossii, Pyrolobusfumarii, Methanopyruskandleri.

Upon adaptation to high temperature, more saturated fatty acids appear in the membrane of bacteria and eukaryotes; in gram-positive bacteria, an increase in the content of iso-branched fatty acids is observed. In some thermophilic bacteria, instead of a complex ether bond, a simple ether bond is present in lipids. Thermophiles show an increase in the content of $\mathrm{G}+\mathrm{C}$ bases in the regions of RNA molecules that form secondary structures. In addition, thermophile proteins are more stable than those of mesophiles, due to an increase in the number of intramolecular interactions. In thermophilic archaea, histones stabilizing the DNA structure are present in the cell [10].

The effect of temperature on the growth of microorganisms is due to its effect on the rate of chemical reactions in the cell and the state of cellular macromolecules 
(membrane viscosity, protein conformation, etc.). An increase in temperature above a critical level leads to irreversible inactivation of cellular components, primarily the denaturation of proteins and nucleic acids, and the death of a microorganism. To assess the lethal effect of temperature on the cells of microorganisms, quantitative parameters are used: the thermal point of extinction (TPE) - the temperature at which a given organism dies in 10 minutes, and the thermal time of extinction (TTE) - the time for which this organism dies at a certain temperature [10].

Thermal tolerance is a polygenic trait that promotes the survival and growth of cells at unusually high temperatures. Although some genes associated with hightemperature growth $(\mathrm{Htg}+)$ have been identified, the ability of cells to accumulate mutations to achieve long-term thermal tolerance remains poorly understood [39].

The taxonomic diversity of thermotolerant oil destructors covers many bacteria. So microbial communities in hot springs are widely studied around the world. In this sense, areas of the Indian Himalayas are valuable ecosystems for studying microbial diversity. In a study by Harmesh S. et al. [39] a total of 140 thermophilic bacteria were isolated from 12 sample samples collected from the hot springs of Manikaran and Yumtang in the Indian Himalayas. Growth properties were studied in bacterial isolates under various conditions and as potential sources of extracellular thermostable hydrolytic enzymes such as protease, amylase, xylanase and cellulase. Based on the isolation of extracellular hydrolases, 51 isolates were identified using $16 \mathrm{~S}$ rRNA gene sequencing. They included 37 different species from 14 different genera, such as Anoxybacillus, Bacillus, Brevibacillus, Brevundimonas, Burkholderia, Geobacillus, Paenibacillus, Planococcus, Pseudomonas, Rhodanobacter, Thermoactinomyces, Thermobacillus, Thermonema and Thiobacillus. Out of 51 hydrolase producing bacteria, 24 isolates showed stability over a wide range of temperature and $\mathrm{pH}$ treatments. In the present study, it was found that three thermotolerant bacteria, namely Thermobacillus sp NBM6, Paenibacillus ehimensis NBM24 and Paenibacillus popilliae NBM68, produced cellulase-free xylanase. These extracellular thermostable hydrolytic enzymes have great commercial potential for use in the oil industry, medicine, and agriculture. In studies by David M.C. et al. [40] ten thermophilic bacterial strains were isolated from manure compost. Phylogenetic analysis based on 16S rRNA genes and biochemical characterization made it possible to identify four different species belonging to four genera: Geobacillus thermodenitrificans, Bacillus smithii, Ureibacillus suwonensis, and Aneurinibacillus thermoaerophilus. PCR-RFLP profiles of the 16S-ITS-23S rRNA region made it possible to distinguish two subgroups among $G$. thermodenitrificans isolates. The isolates were screened for thermo-tolerant hydrolytic activity $\left(60-65^{\circ} \mathrm{C}\right)$. Thermo-tolerant lipolytic activity was detected for $G$. thermodenitrificans, A. thermoaerophilus, and B. smithii. In the group of $G$. thermodenitrificans, the activity of thermotolerant protease, $\alpha$-amylase, and xylanase was also observed. The authors concluded that these species represent a source of potential new thermostable enzymes for industrial use.

The thermotolerant bacterium PHS1 isolated from a hot spring in Pohang, Korea, was able to grow on benzene, toluene, ethylbenzene and xylene (BTEX) as the sole carbon source. Strain PHS1 was a Gram-negative, rod-shaped cell with optimal growth at $42^{\circ} \mathrm{C}$ and $\mathrm{pH} 7.2$. According to the analysis of $16 \mathrm{~S}$ rRNA, the strain PHS1 showed the greatest similarity with Ralstonia (formerly called Alcaligenes eutrophus). However, unlike its closest known species, Ralstonia, strain PHS1 could use toluene, ethylbenzene, o-xylene and both $\mathrm{m}$ - and o-cresol. According to the authors, the degradation of o-xylene by strain PHS1 is especially important, since o-xylene is a compound of significant environmental interest due to its instability. And very few microorganisms use o-xylene as their sole carbon source. It was found that strain PHS1 transformed o-xylene into 2,3-dimethylphenol by direct oxygenation of the aromatic 
ring. The unique properties of strain PHS1, such as heat resistance and degradability of o-xylene, may be important for the treatment of industrial effluents contaminated with BTEX [41].

From the oil-contaminated soil taken from the mud pit at the Khangiran oil and gas field (northeast of Iran), a thermally tolerant actinobacterial strain RIPIT degrading crude oil was isolated. RIPIT was strictly aerobic, catalase and oxidase-positive. The strain grew with $\mathrm{NaCl}(3-5 \%)$ at $25-55^{\circ} \mathrm{C}$ (opt. $45^{\circ} \mathrm{C}$ ) and at $\mathrm{pH} 6.0-9.5$ (opt. $\mathrm{PH} 7.0$ ). Based on multiphase taxonomic data, the authors suggested that RIPIT is a new species of the genus Prauserella, which was given the name Prauserella oleivorans sp. [42].

Raza C. et al. [43] when studying indigenous oil-oxidizing microorganisms in Pakistan soils, revealed that the main oil destructors in the soil of the Rajan field are pseudomonads and bacilli, as well as representatives of the genera Klebsiella, Acinetobacter, Clostridium, Erwinia, and Streptococcus. At the same time, the authors isolated strains of the genera Acinetobacter, Amphibacillus, Arthrobacter, Bacillus, Corynebacterium, Flavobacterium, Klebsiella, Lactobacillus, Listeria, Moraxella, Providensia and Pseudomonas from soil samples from the Missa Kasval deposit. An experiment on the destruction of oil by bacterial monocultures showed that at $37^{\circ} \mathrm{C}$ and an initial oil concentration of $1 \%$, the representatives of Pseudomonas and Bacillus were the most effective oil destructors: after 15 days of cultivation, they oxidized to $20 \%$ and up to $16 \%$ of oil, respectively. Mnif S. et al. [44] isolated a number of oiloxidizing bacteria from various Tunisian deposits, attributed by the authors to the genera Geobacillus, Bacillus, Brevibacillus, Pseudomonas, Lysinibacillus, Achromobacter, and Halomonas. Strains grew on oil in the presence of various salt concentrations $(1-10 \%)$ and in the temperature range $37-55^{\circ} \mathrm{C}$. Strain $\mathrm{C} 450 \mathrm{R}$, identified by the authors as $P$. aeruginosa, during oil growth (2\%) produced glycolipid biosurfactants that reduced the surface tension of the culture medium from 68 to 35 $\mathrm{mN} / \mathrm{m}$. Rajaei S. et al. [45] isolated from the oat rhizosphere in Khuzestan (Iran) thermotolerant oil-oxidizing bacterial strains of the genera Acinetobacter, Pseudomonas, Enterobacter, Stenotrophomonas, Bacillus, Achromobacter, Ochrobacterium, Paenibacillus, Microbacteriumium, Curtobacterium and Sphingobacterium. The catabolic genes responsible for the destruction of alkanes and aromatic compounds were identified in these bacteria. It was shown in the work that oat rhizospheric bacteria are capable of utilizing oil in the soil by $40.5 \%$ within 10 days of cultivation at an initial oil concentration of $2.5 \%$. In the work of Y. A. Delegan [46] the ability to utilize hydrocarbons at temperatures up to $50^{\circ} \mathrm{C}$ in 18 thermotolerant cultures has been analyzed. Strains were identified as representatives of the genera Gordonia, Rhodococcus, Paenibacillus and Deinococcus. The most effective thermotolerant destructors are Gordonia sp. 1D, Gordonia sp. 1G, Rhodococcus erythropolis Par7, $R$. pyridinivorans L5A-BSU, Rhodococcus sp. Par6, Deinococcus sp. A2-6, and utilized oil both at $24^{\circ} \mathrm{C}$ and at $45^{\circ} \mathrm{C}$, in the presence of oil up to $10 \%$ and salt up to $7 \%$.

In addition to bacteria, there are also a number of reports on the isolation of natural samples of fungi with oil-oxidizing ability. So, Obuekwe C.O. et al. [47] reported the isolation of Fusarium lateritium, Drechslera sp. and Papulaspora sp. from the saline soils of the desert in Kuwait. The strains of these fungi were able to utilize oil as a carbon source. The authors showed that two strains (Fusarium lateritium, Drechslera sp.) grew in the presence of $10 \%$ salt, Papulaspora sp. - in the presence of $5 \%$ salt. Salt as a stress factor did not significantly affect the degradation of oil by fungi, but the degree of degradation depended on the presence of nutrients in the medium. Teerapatsakul C. et al. [48] studied the biodegradation of phenanthrene, fluorene, and pyrene by the thermotolerant fungal strain RYNF13, isolated from decayed acacia wood (Rayong Province, Thailand). Strain RYNF13 has been identified as Trametespolyzona. The fungus showed a high ability for biodegradation of PAHs at a concentration of 100 
$\mathrm{mg} / \mathrm{L}$. Complete degradation of phenanthrene was observed within 18 days after incubation at $30^{\circ} \mathrm{C} .90 \%$ of fluorene and $52 \%$ of pyrene were degraded under the same conditions. At a temperature of $42^{\circ} \mathrm{C}$, the RYNF13 strain degraded approximately $68 \%$ of phenanthrene, $48 \%$ of fluorene, and $30 \%$ of pyrene for 32 days. Thus, the strain RYNF13 is a potential fungus for PAH bioremediation, especially in a tropical environment where the temperature can be above $40^{\circ} \mathrm{C}$. Strain RYNF13 isolated three different ligninolytic enzymes, manganese peroxidase, laccase and lignin peroxidase during $\mathrm{PAH}$ biodegradation at $30^{\circ} \mathrm{C}$. With an increase in temperature from $30^{\circ} \mathrm{C}$ to $37^{\circ} \mathrm{C}$ and $42^{\circ} \mathrm{C}$, only two ligninolytic enzymes (manganese peroxidase and laccase) were detected. Manganese peroxidase was the main enzyme produced by the fungus.

The choice of recovery method for contaminated soil and water depends to a large extent on the place of production and oil composition. The composition of oil in different countries and, correspondingly, deposits varies greatly. Thus, Venezuela, Kuwait and Iran produce heavy oil with a high sulfur content, and Nigeria, the United Arab Emirates, Angola and Libya are suppliers of high-quality light oil, almost free of sulfur. But light oil is also dangerous because it is enriched with volatile toxic components [49].

The leader in terms of oil production among the CIS countries, whose territories are located in regions with a hot climate, is Kazakhstan. The largest oil fields on the territory of this state are Kashagan, Karashyganak, Uzen, Zhetybai, Tengiz, Zhanazhol and Kumkol. The density of the produced oil mainly ranges from 0.79 to $0.82 \mathrm{~g} / \mathrm{cm}^{3}$, the tar content is from $1.14 \%$ (Tengiz) to $8.2 \%$ (Kumkol), and sulfur is $0.5-1.1 \%$. The Uzen oil has a high density $\left(0.84-0.87 \mathrm{~g} / \mathrm{cm}^{3}\right)$, tar content up to $20 \%$ and sulfur content up to $2 \%$; Zhetybai oil is medium in density, viscous, and also highly paraffinic, since the temperature of its yield loss is $+33^{\circ} \mathrm{C}[50]$.

There is the following world classification of oil by density: super light - up to $0.780 \mathrm{~g} / \mathrm{cm}^{2}$; ultralight $-0.781-0.820 \mathrm{~g} / \mathrm{cm}^{3}$; light $-0.821-0.870 \mathrm{~g} / \mathrm{cm}^{3}$; average $0.871-0.920 \mathrm{~g} / \mathrm{cm}^{3}$; heavy $-0.921-1,000 \mathrm{~g} / \mathrm{cm}^{3}$; superheavy - over $1,000 \mathrm{~g} / \mathrm{cm}^{3}$ and natural bitumen - whose density is also higher than $1000 \mathrm{~g} / \mathrm{cm}^{3}$, viscosity more than $10000 \mathrm{mPa} s$ [51]. In accordance with this classification, oil extracted from various fields of Kazakhstan, in terms of density, relates mainly to light and medium, although dense oil is also found. The higher the density of the produced oil, the less it is subject to biodegradation, since it contains a large amount of high molecular weight components such as resins, asphaltenes, bitumen.

In compiling a microbial consortium, which is planned to be used to clean oil from territories in a hot climate, data are also needed on the ability of bacteria to utilize hydrocarbons in the presence of salt in the medium, the maximum possible concentration of pollutant and the minimum allowable soil moisture. This information will allow to estimate the cost of irrigation of the plot treated by the preparation, as well as to reduce the concentration of oil and salt using available methods.

Microorganisms adapted to the climatic conditions of their habitat regions are capable of efficiently degrading oil even under seasonal temperature differences, low soil moisture, and soil salinity [52]. The specific climatic conditions of the regions under consideration for a long time have been a breeding factor contributing to the survival of indigenous microorganisms with certain properties: the ability to withstand high (average up to $50^{\circ} \mathrm{C}$ ) temperatures, salinity up to $7 \%$ and lack of moisture in the soil. It is the bacteria with such properties that are capable of efficiently utilizing oil in territories with a hot arid climate. Long-term studies conducted in various geographical regions show that microorganisms belonging to different taxonomic groups and significantly differing in physiological and metabolic characteristics are capable of degrading hydrocarbon pollutants. 
The taxonomic diversity of thermotolerant bacteria allows them to be used in remediation technologies not only as monocultures, but also to form microbial associations in order to accelerate and increase the overall efficiency of the degradation process.

The enzymes used by thermotolerant bacteria for the destruction of hydrocarbons operate at higher temperatures than the enzymes of common mesophilic destructors, which makes thermotolerant strains promising remediation agents for oil-contaminated soils and water at high ambient temperatures.

In the framework of the project "Thermotolerant microorganisms for bioremediation of oil-contaminated soils of Western Kazakhstan" (state registration number 0118PK00176), as a result of the screening of collection and newly isolated cultures of oil-oxidizing microorganisms, we selected 38 cultures that showed good growth on oil at $35^{\circ} \mathrm{C}, 16$ cultures - at $40^{\circ} \mathrm{C}$ and 19 cultures - at $50^{\circ} \mathrm{C}$. Further studies showed that the destruction of oil by the studied cultures was $23.7-70.5 \%$ [53]. The most active strains of oil-oxidizing microorganisms were identified by Sanger sequencing and assigned to the genera Pseudomonas, Bacillus, Achromobacter, Rhodococcus, Brevibacillus, Gordonia [54]. For further work, we will select the most active thermotolerant strains of microorganisms and compose consortia.

\section{CONCLUSION}

To solve the problem of oil pollution in conditions of elevated climatic temperatures, an effective approach has not yet been proposed. When developing microbial preparations, as well as the technology for cleaning soil and water from oil in hot arid climates, it should be taken into account that the climate of such regions is characterized by large daily temperature differences, salinity, and low soil moisture. Most of the known microorganisms-oil destructors are not adapted to such conditions, which leads to a decrease in the efficiency of the destruction of pollutant. For the destruction of oil in a hot climate, it is advisable to use thermotolerant microorganisms for which such conditions are not stressful. The study of the biology of such microorganisms is important, from the point of view of their use as a part of biological products for the bioremediation of oil-contaminated soils. The development of biological products based on consortia of thermotolerant bacteria and their use for cleaning soils and water at high temperatures can be a promising solution to the problem of oil pollution in Kazakhstan.

\section{Acknowledgements}

The work was supported by the Ministry of Education and Science of the Republic of Kazakhstan (grant No AP05132128).

\section{REFERENCES}

1. Karlapudi A.P., Venkateswarulu T.C., Tammineedi J., Kanumuri L., Bharath K.R., Dirisala V.R., Kodali V.P. Role of biosurfactants in bioremediation of oil pollution-a review. Petroleum, 2018, vol. 4, no 3, pp. 241-249. https://doi.org/10.1016/j.petlm.2018.03.007

2. Vik E.A., Bardos P. Remediation of Contaminated Land Technology Implementation in Europe: A Report from the Contaminated Land Rehabilitation Network for Environmental Technologies (CLARINET). Umweltbundesamt/Federal Environment Agency, Austria, 2002. 180 p.

3. https://kazakhstan.orexca.com/rus/facts_kazakhstan.shtml 
4. Veerasingam S., Vethamony P., Mani Murali R., Babu, M.T. Sources, Vertical Fluxes and Accumulation of Petroleum Hydrocarbons in Sediments from the Mandovi Estuary, West Coast of India. Int. J. Environ. Res., 2015, vol. 9, no 1, pp. 179-186. https://doi.org/10.22059/IJER.2015.887

5. Anastasios I. Zouboulis, Panagiotis A. Moussas, Savvina G. Psaltou Groundwater and Soil Pollution: Bioremediation. In book: Reference Module in Earth Systems and Environmental Sciences, 2018, pp. 1037-1044. 10.1016/B978-0-12409548-9.11246-1.

6. Sunita J. Varjani Microbial degradation of petroleum hydrocarbons. Bioresource Technology, 2017, vol. 223, pp. 277-286. https://doi.org/10.1016/j.biortech.2016.10.037

7. Borah Debajit, Yadav R.N.S. Bioremediation of petroleum based contaminants with biosurfactant produced by a newly isolated petroleum oil degrading bacterial strain. Egyptian Journal of Petroleum, 2017, vol. 26, pp. 181-188. https://doi.org/10.1016/j.ejpe.2016.02.005

8. Zhukov D.V., Murygina V.P., Kalyuzhny S.V. Kineticheskiye zakonomernosti biodegradatsii alifaticheskikh uglevodorodov bakteriyami Rhodococcus ruber i Rhodococcus erythropolis [Kinetic patterns of biodegradation of aliphatic hydrocarbons by the bacteria Rhodococcus ruber and Rhodococcus erythropolis]. Prikladnaya biokhimiya i mikrobiologiya - Applied Biochemistry and Microbiology, 2007, vol. 43, no 6, pp.657-663.

9. Adnan B. Al-Hawash, Maytham A. Dragh, Shue Li, Ahmad Alhujaily Hayder A .Abbood, Xiaoyu Zhang Fuying M. Principles of microbial degradation of petroleum hydrocarbons in the environment. The Egyptian Journal of Aquatic Research, 2018, vol. 44, no 2, pp. 71-76. https://doi.org/10.1016/j.ejar.2018.06.001

10. Chernyavskaya M.I., Sidorenko A.V., Golenchenko S.G., Lysak V.V., Samsonova A.S. Ekologicheskaya mikrobiologiya. Uchebno metodicheskoye posobiye [Ecological microbiology. Educational-methodical manual]. Minsk, BSU, 2016. 60 p.

11. Bisht, P. P., Bhargava B., Sharma S., Kumar V., Sharma K.D. Bioremediation of polyaromatic hydrocarbons (PAHs) using rhizosphere technology. Braz. J. Microbiol, 2015, vol. 46, no 1, pp. 7-21. https://doi.org/10.1590/S1517838246120131354

12. Aislabie J., Saul D., Foght J. Bioremediation of hydrocarbon-contaminated polar soils. Extremophiles, 2006, vol. 10, pp. 171-179. https://doi.org/10.1007/s00792005-0498-4

13. Okoh A.I. Biodegradation alternative in the cleanup of petroleum hydrocarbon pollutants Biotechnol. Mol. Biol. Rev., 2006, vol. 1, no 2, pp. 38-50. http://www.academicjournals.org/BMBR

14. Thamer M., Al-Kubaisi A.R., Zahraw Z., Abdullah H. A., Hindy I., Khadium A. A. Biodegradation of Kirkuk light crude oil by Bacillus thuringiensis. Northern of Iraq Nat. Sci., 2013, vol. 5, no 7, pp. 865-873. https://doi.org/10.4236/ns.2013.57104

15. Haritash A., Kaushik C. Biodegradation aspects of polycyclic aromatic hydrocarbons (PAHs): a review. J. Hazard. Mater., 2009, vol. 169, no 1-3, pp. 1-15. https://doi.org/10.1016/j.jhazmat.2009.03.137

16. McNally D.L., Mihelcic J.R., Lueking D.R. Biodegradation of three-and fourring polycyclic aromatic hydrocarbons under aerobic and denitrifying conditions. Environ. Sci. Technol., 1998, vol. 32, no. 17, pp. 2633-2639. https://doi.org/10.1021/es980006c

17. Meng L., Li H., Bao M., Sun P. Metabolic pathway for a new strain Pseudomonas synxantha LSH-7: from chemotaxis to up take of n-hexadecane. Sci. Rep., 2017, vol. 7, pp. 390-398. https://doi.org/10.1038/srep39068. 
18. Meckenstock R.U., Boll M., Mouttaki H., Koelschbach J.S., Tarouco P.C., Weyrauch P., Dong X., Himmelberg A.M. Anaerobic degradation of benzene and polycyclic aromatic hydrocarbons. J. Mol. Microbiol. Biotechnol., 2016, vol. 26, pp. 92118. https://doi.org/10.1159/000441358

19. Wilkes H., Buckel W., Golding B.T., Rabus R. Metabolism of hydrocarbons in n-Alkane utilizing anaerobic bacteria. J. Mol. Microbiol. Biotechnol., 2016, vol. 26, pp. 138-151. https://doi.org/10.1159/000442160

20. Abbasian F., Lockington R., Mallavarapu M., Naidu R. A comprehensive review of aliphatic hydrocarbon biodegradation by bacteria. Appl. Biochem. Biotechnol., 2015, vol. 176, no 3, pp. 670-699. https://doi.org/10.1007 / s12010-015-1603-5

21. Heider J., Spormann A.M., Beller H.R., Widdel F. Anaerobic bacterial metabolism of hydrocarbons. FEMS Microbiol. Rev., 1999, vol. 22, pp. 459-473. https://doi.org/10.1111/j.1574-6976.1998.tb00381.x

22. Foght J.M. Anaerobic biodegradation of aromatic hydrocarbons: pathways and prospects. J. Mol. Micobiol. Biotechnol., 2008, vol. 15, pp. 93-120. https://doi.org/10.1159/000121324

23. Abed R.M.M., Al-Thukair A., de Beer D. Bacterial diversity of a cyanobacterial mat degrading petroleum compounds at elevated salinities and temperatures. FEMS Microbiol Ecol., 2006, vol. 57, pp. 290-301. https://doi.org/10.1111/j.1574-6941.2006.00113.x

24. Kleikemper J., Schroth M.H., Sigler W.V., Schmucki M., Bernasconi S.M., Zeyer J. Activity and diversity of sulfate-reducing bacteria in a petroleum hydrocarboncontaminated aquifer. Appl Environ Microbiol., 2002, vol. 68, pp. 1516-1523. https://doi.org/10.1128/AEM.68.4.1516-1523.2002

25. Qin X., Tang J., Li D., Zhang Q. Effect of salinity on the bioremediation of petroleum hydrocarbons in a saline alkaline soil. Lett. Appl. Microbiol., 2012, vol. 55, no 3, pp. 210-217. https://doi.org/10.1111/j.1472-765X.2012.03280.x

26. Ebadi A., Khoshkholgh Sima N.A., Olamaee M., Hashemi M., Ghorbani N. R. Effective bioremediation of a petroleum-polluted saline soil by a surfactant-producing Pseudomonas aeruginosa consortium. J. Adv. Res., 2017, vol. 8, no 6, pp. 627-633. https://doi.org/10.1016/j.jare.2017.06.008

27. Ben Ali Gam Z., Abdelkafi S., Casalot L., Tholozan J. L., Oueslati R. and Labat M. Modicisalibacter tunisiensis gen. nov., sp. nov., an aerobic, moderately halophilic bacterium isolated from an oilfield-water injection sample, and emended description of the family Halomonadaceae Franzmann et al. 1989 emend Dobson and Franzmann 1996 emend. Ntougias et al. 2007. International Journal of Systematic and Evolutionary Microbiology, 2007, vol. 57, pp. 2307-2313. https://doi.org/10.1099/ijs.0.65088-0 doi:10.1099/ijs.0.65088-0

28. WangY.N., ChiC.Q., CaiM., LouZ.Y., TangY.Q., ZhiX.Y. et al. Amycolicicoccus sub. flavus gen. nov., sp. nov., an actinomycete isolated from a saline soil contaminated by crude oil. Int. J. Syst. Evol. Microbiol., 2010, vol. 60, pp. 638-643. https://doi.org/10.1099/ijs.0.010546-0

29. Bonomo R., Cennamo G., Purrello R., Santoro A., Zappala R. Comparison of three fungall accases from Rigidoporuslignosus and Pleurotusostreatus: correlation between conformation changes and catalytic activity. J. Inorg. Biochem., 2001, vol. 83, no 1, pp. 67-75. https://doi.org/10.1016/s0162-0134(00)00130-6

30. Bossert I., Bartha R. The fate of petroleum in soil ecosystems. In: R.M. Atlas (Ed.) Petroleum Microbiology, Macmillan, New York, 1984, pp. 435-473.

31. Thavasi R., Jayalakshmi S., Balasubramanian T., Banat I.M. Effect of salinity, temperature, $\mathrm{pH}$ and crude oil concentration on biodegradation of crude oil by Pseudomonas aeruginosa. J. Biol. Environ. Sci., 2007, vol. 1, no 2, pp. 51-57. 
32. Pawar R. The effect of soil $\mathrm{pH}$ on bioremediation of polycyclic aromatic hydrocarbons (PAHS). J. Bioremediat. Biodegrad., 2015, vol. 6, no 3, pp. 1-14. https://doi.org/10.4172/2155-6199.1000291

33. Varjani S.J., Rana D.P., Jain A.K., Bateja S., Upasani V.N. Synergistic ex-situ biodegradation of crude oil by halotolerant bacterial consortium of indigenous strains isolated from on shore sites of Gujarat, India. Int. Biodeterior. Biodegrad., 2015, vol. 103, pp. 116-124. https://doi.org/10.1016/j.ibiod.2015.03.030

34. Varjani S.J., Upasani V.N. Biodegradation of petroleum hydrocarbons by oleophilic strain of Pseudomonas aeruginosa NCIM 5514. Bioresour. Technol., 2016, vol. 222, pp. 195-201. https://doi.org/10.1016/j.biortech.2016.10.006

35. Semple K.T., Morriss A., Paton G.I. Bioavailability of hydrophobic organic contaminants in soils: fundamental concepts and techniques for analysis. Eur. J. Soil. Sci., 2003, vol. 54, no 4, pp. 809-818. http://dx.doi.org/10.1046/j.13510754.2003.0564.x

36. Iqbal J. Effect of temperature on efficiency of insitu bioremediation technology: A laboratory microcosmand field study. PhD Thesis. Louisiana State University and Agricultural and Mechanical College, 2003.

37. Fiedler L., Gilbert E. Introduction to in situ bioremediation of groundwater. United States Environmental Protection Agency, 2013. https://semspub.epa.gov/work/11/171054.pdf

38. Delegan Ya.A., Vetrova A.A., Chernyavskaya M.I., Titok M.A., Filonov A. E. Termotolerantnyye aktinomitsety kak agenty remediatsii neftezagryaznennykh gruntov $\mathrm{i}$ vod $\mathrm{v}$ usloviyakh zharkogo aridnogo klimata [Thermo-tolerant actinomycetes as agents of remediation of oil-contaminated soils and waters in hot arid climate]. Izvestiya Tul'skogo gosudarstvennogo universiteta Yestestvennyye nauki - Bulletin of the Tula State University of Natural Sciences, 2015, vol. 4, pp. 248-258.

39. Harmesh S., Ajar N. Y., Atul K. S., Surendra S., Rajeev K., Anil K. S. Hot springs of Indian Himalayas: potential sources of microbial diversity and thermostable hydrolytic enzymes. 3 Biotech., 2017, vol. 7, no 2, pp. 118. https://doi.org/10.1007 / s13205-017-0762-1

40. David M.C., Fatma M. M., Maurice B., Marc S., Beauregard M. Identification of Thermophilic Bacterial Strains Producing Thermotolerant Hydrolytic Enzymes from Manure Compost. Indian J Microbiol. Mar, 2012, vol. 52, no 1, pp. 41-47. https://doi.org/10.1007/s12088-011-0156-8

41. Lee S.K., Lee S.B. Isolation and characterization of a thermotolerant bacterium Ralstonia sp. strain PHS1 that degrades benzene, toluene, ethyl benzene, ando-xylene. Appl Microbiol Biotechnol., 2001 vol. 56, no 1-2, pp. 270-275. https://doi.org/10.1007/s002530100608

42. Dastgheib C.M., Tirandaz H., Moshtaghi N. M., Ramezani M., Shavandi M., Amoozegar M.A., Ventosa A. Prauserella oleivorans sp. nov., a halophilic and thermotolerant crude-oil-degrading actinobacterium isolated from an oil-contaminated mud pit. Int. J. Syst. Evol. Microbiol., 2017, vol. 67, no 9, pp. 3381-3386. https://doi.org/10.1099/ijsem.0.002124

43. Raza C., Bila 1A., Jahan N. Evaluation of biodegradation potential of bacteria in crude oil contaminated soil. Biologia (Pakistan), 2010, vol. 56, no 1-2, pp. 77-85.

44. Mnif S., Chamkha M., Labat M., Sayadi S. Simultaneous hydrocarbon biodegradation and biosurfactant production by oil field-selected bacteria. J. Appl. Microbiol., 2011, vol. 111, pp. 525-536. https://doi.org/10.1111/j.13652672.2011.05071.X

45. Rajaei S., Seyedi S.M., Raiesi F., Shiran B., Raheb J. Characterization and Potentials of Indigenous Oil-Degrading Bacteria Inhabiting the Rhizosphere of Wild 
Oat (Avena Fatua L.) in South West of Iran. Iran J Biotech., 2013, vol. 11, no 1, pp. 32 40. https://doi.org/10.5812 / IJB.9334

46. Delegan Y.A. Termotolerantnyye bakterii-destruktory uglevodorodov nefti [Thermo-tolerant bacteria-decomposers of oil hydrocarbons]: Diss. Cand. biol. Sciences: 03.01.06 - Pushchino, 2016, 153 p.

47. Obuekwe C.O., Badrudeen A.M., Al-Saleh E., Mulder J.L. Growth and hydrocarbon degradation by three desert fungi under conditions of simultaneous temperature and salt stress. Intern. Biodeter. Biodegrad., 2005, vol. 56, pp. 197-205 https://doi.org/10.1016/j.ibiod.2005.05.005

48. Teerapatsakul C., Pothiratana C., Chitradon L., Thachepan S. Biodegradation of polycyclic aromatic hydrocarbons by a thermotolerant white rot fungus Trametespolyzona RYNF13. J Gen. Appl. Microbiol., 2017, vol. 62, no 6, pp. 303-312. https://doi.org/10.2323/jgam.2016.06.001

49. Tsaprailis $H$. Properties of dilbit and conventional crude oils. Alberta Innovates Energy and Environmental Solutions, Report 66030, 2013. http://www.ci.benicia.ca.us/vertical/sites/\%7BF991A639-AAED-4E1A-9735-

86EA195E2C8D\%7D/uploads/79_Haralampos_Tsaprailis_Properties_of_Dilbit_and_C onventional_Crude_Oil_February_2014.pdf.

50. http://www.mineral.ru/Facts/stat/124/214/index.html

51. https://petrodigest.ru/articles/neft/heavy-crude-oil

52. Abed R.M.M., Al-Sabahi J., Al-Maqrashi F., Al-Habsi A., Al-Hinai M. Characterization of hydrocarbon-degrading bacteria isolated from oil-contaminated sediments in the Sultanate of Oman an devaluation of bioaugmentation and biostimulation approaches in microcosm experiments. International Biodeterioration \& Biodegradation, 2014, vol. 89, pp. 58-66. https://doi.org/10.1016/j.ibiod.2014.01.006

53. Aitkeldiyeva S.A., Faizulina E.R., Auezova O.N., Tatarkina L.G., Spankulova G.A. Isolation and study of thermotolerant oil-oxidizing microorganisms. News of the NAS RK. Series of Biology and Medicine, 2019, vol. 2, pp. 56-62. https://doi.org/10.32014/2019.2519-1629.21

54. Aitkeldieva S.A., Fayzulina E.R., Auezova O.N., Tatarkina L.G., Spankulova G..A. Selection and study of thermotolerant cultures of oil-oxidizing microorganisms. Mikrobiologiya i virusologiya - Microbiology and virology, 2018, vol. 3, pp. 40-50.

\section{МҰНАЙМЕН ЛАСТАНҒАН ТОПЫРАҚТЫ ҚАЛПЫНА КЕЛТІРУ ҮШІН ТЕРМОТӨЗІМДІ МИКРОАҒЗАЛАРДЫ ҚОЛДАНУДЫН МУМКІНДІКТЕРІ}

Айткельдиева С.А., Файзулина Э.Р., Татаркина Л.Г., Алимбетова А.В., Ауэзова О.Н., Спанкулова Г.А.

Микробиология жсне вирусология вылыми-өндірістік орталывы, Бөгенбай батыр көш., 105Алматы құ., 050010, Қазақ̧стан sa.kz@list.ru, ecomicrolab@gmail.com

\section{ТYЙІН}

Әлемдегі мұнай кен орындарының көпшілігі жоғары температуралық режимі бар географиялық аймақтарда шоғырланған. Ыстық климат жағдайында аумақтарды қалпына келтірудің басты мәселерінің бірі, жоғары температура мұнайдың тұтқырлығын төмендетеді және оның жерге терең диффузиясын тездетеді. Бұл әдеттегі әдістермен топырақ жамылғысын қалпына келтіру процестерін едәуір қиындатады. Балама ретінде жоғары 
температураға және төмен ылғалдылыққа төзімді мұнай тотықтырғыш микроағзаларды қолдана отырып биоремедиация бола алады. Бұл әр түрлі елдердің ғалымдарының термотолерантты микроағзаларды мұнай мен мұнай өнімдерінен ластанған топырақты қалпына келтіру кезінде қолдану мақсатында жүргізген зерттеулерін талдауға арналған шолу. Температура, оттегі, рН, тұздылық, аэрация, қоректік заттардың болуы және т.б. сияқты қоршаған ортаның негізгі экологиялық факторларының әсері, термоттөзімді көмірсутек тотықтырғыш микроағзаларының өміршендігі мен тіршілік белсенділігі туралы мәліметтер келтірілген. Термоттөзімді микроағзалар үшін биохимиялық және молекулярлық-генетикалық сипаттамалардың мысалдары келтірілген. Термотөзімді көмірсутек тотықтырғыш микроағзалардың таксономиялық әртүрлілігі көрсетілген, сонымен қатар белсенді штамдармен мұнайдың жеке компоненттерінің ыдырауының мысалдары келтірілген. Қазақстанның негізгі кен орындарындағы мұнайдың физикалық-химиялық көрсеткіштері туралы мәліметтерді ұсынылған.

Негізгі сөздер: термотөзімді микроағзалар, биоремедиация, мұнай, мұнай ыдыратқыштар, температура

\section{ПЕРСПЕКТИВЫ ИСПОЛЬЗОВАНИЯ ТЕРМОТОЛЕРАНТНЫХ МИКРООРГАНИЗМОВ ДЛЯ РЕМЕДИАЦИИ НЕФТЕЗАГРЯЗНЕННЫХ ПОЧВ}

Айткельдиева С.А., Файзулина Э.Р., Татаркина Л.Г., Алимбетова А.В., Ауэзова О.Н., Спанкулова Г.А.

Научно-производственный центр микробиологии и вирусологии ул. Богенбай батыра, 105, г. Алматы, 050010, Казахстан sa.kz@list.ru, ecomicrolab@gmail.com

\section{АБСТРАКТ}

Большинство нефтяных месторождений в мире сконцентрировано в географических зонах с повышенным температурным режимом. Одной из главных проблем ремедиации территорий в условиях жаркого климата является тот факт, что высокие температуры снижают вязкость нефти и, таким образом, ускоряют ее диффузию вглубь грунта. Это значительно усложняет процессы восстановления почвенных покровов обычными методами. Альтернативой может служить биоремедиация с помощью нефтеокисляющих микроорганизмов, устойчивых к высоким температурам и пониженной влажности. Представленный обзор посвящен анализу исследований термотолерантных микроорганизмов учеными разных стран с целью их использования при ремедиации загрязненных почв от нефти и нефтепродуктов. Приведены данные по влиянию основных экологических факторов окружающей среды, таких как: температура, кислород, pH, соленость, аэрация, наличие питательных веществ и др., на жизнеспособность и жизнедеятельность термотолерантных углеводородокисляющих микроорганизмов. Приведены примеры характерных для термотолерантных микроорганизмов биохимических и молекулярно-генетических признаков. Показано таксономическое 
разнообразие термотолерантных углеводородокисляющих микроорганизмов, a также приведены примеры деградации отдельных компонентов нефти активными штаммами. Представлены данные по физико-химическим показателям нефти основных месторождений Казахстана.

Ключевые слова: термотолерантные микроорганизмы, биоремедиация, нефть, нефтедеструкторы, температура 